\title{
Effects of adding sodium dichloroacetate to low-protein diets on nitrogen balance and amino acid metabolism in the portal- drained viscera and liver of pigs
}

\author{
Weizhong Sun ${ }^{1 \dagger}$, Yunxia Li ${ }^{2+}$, Zhiru Tang ${ }^{1}$, Huiyuan Chen ${ }^{1}$, Ke Wan ${ }^{1}$, Rui $\mathrm{An}^{1}$, Liuting Wu${ }^{1}$ and Zhihong Sun ${ }^{1 *}$ (D)
}

\begin{abstract}
Background: Identifying regulatory measures to promote glucose oxidative metabolism while simultaneously reducing amino acid oxidative metabolism is one of the foremost challenges in formulating low-protein (LP) diets designed to reduce the excretion of nitrogen-containing substances known to be potential pollutants. In this study, we investigated the effects of adding sodium dichloroacetate (DCA) to a LP diet on nitrogen balance and amino acid metabolism in the portal-drained viscera (PDV) and liver of pigs.

To measure nitrogen balance, 18 barrows $(40 \pm 1.0 \mathrm{~kg}$ ) were fed one of three diets ( $n=6$ per group): $18 \%$ crude protein (CP, control), 13.5\% CP (LP), and 13.5\% CP + $100 \mathrm{mg}$ DCA/kg dry matter (LP-DCA). To measure amino acid metabolism in the PDV and liver, 15 barrows $(40 \pm 1.0 \mathrm{~kg})$ were randomly assigned to one of the three diets $(n=5$ per group). Four essential amino acids (Lys, Met, Thr, and Trp) were added to the LP diets such that these had amino acid levels comparable to those of the control diet.

Results: The LP-DCA diet reduced nitrogen excretion in pigs relative to that of pigs fed the control diet $(P<0.05)$, without any negative effects on nitrogen retention $(P>0.05)$. There were no differences between the control and LP-DCA groups with respect to amino acid supply to the liver and extra-hepatic tissues in pigs $(P>0.05)$. The net release of ammonia into the portal vein and production rate of urea in the liver of pigs fed the LP-DCA diet was reduced relative to that of pigs fed the control and LP diets $(P<0.05)$.
\end{abstract}

Conclusion: The results indicated that addition of DCA to a LP diet can efficiently reduce nitrogen excretion in pigs and maximize the supply of amino acids to the liver and extra-hepatic tissues.

Keywords: Amino acid metabolism, Low-protein diet, Nitrogen excretion, Pig, Sodium dichloroacetate

\section{Background}

The pork sector benefits the livelihoods of millions of producers and consumers but is also a source of serious nitrogen pollution. It is estimated that, worldwide, the

\footnotetext{
* Correspondence: sunzh2002cn@aliyun.com

'Weizhong Sun and Yunxia Li contributed equally to this work.

'Laboratory for Bio-feed and Molecular Nutrition, College of Animal Science and Technology, Southwest University, Chongqing 400715, People's Republic of China

Full list of author information is available at the end of the article
}

pork sector releases $10 \mathrm{Tg}$ of nitrogen into the environment annually, approximately $70 \%$ of which is lost to watercourses in the form of organic nitrogen and nitrates; the remainder is emitted into the atmosphere as nitrogenous gases (e.g., $\mathrm{NH}_{3}, \mathrm{NO}_{\mathrm{X}}$, and $\mathrm{N}_{2} \mathrm{O}$ ) [1]. In the past few decades, low-protein (LP) diets supplemented with indispensable amino acids have shown the potential to reduce nitrogen excretion [2-4], and numerous studies have shown no adverse effects on the growth

C The Author(s). 2020 Open Access This article is licensed under a Creative Commons Attribution 4.0 International License, which permits use, sharing, adaptation, distribution and reproduction in any medium or format, as long as you give appropriate credit to the original author(s) and the source, provide a link to the Creative Commons licence, and indicate if changes were made. The images or other third party material in this article are included in the article's Creative Commons licence, unless indicated otherwise in a credit line to the material. If material is not included in the article's Creative Commons licence and your intended use is not permitted by statutory regulation or exceeds the permitted use, you will need to obtain permission directly from the copyright holder. To view a copy of this licence, visit http://creativecommons.org/licenses/by/4.0/. The Creative Commons Public Domain Dedication waiver (http://creativecommons.org/publicdomain/zero/1.0/) applies to the data made available in this article, unless otherwise stated in a credit line to the data. 
performance of pigs when the dietary crude protein $(\mathrm{CP})$ content was reduced by less than $2-3 \%$ [2, 5-7]. However, when the dietary protein content is reduced by $\geq 3 \%$, it becomes necessary to add large amounts of amino acids to LP diets to meet animal requirements; otherwise pigs tend to show poor growth [8-13]. Nevertheless, it is deemed inadvisable to reduce the dietary $\mathrm{CP}$ content while simultaneously supplementing the diet with amino acids, as this increases both nitrogen intake and feed cost and reduces economic performance.

Urinary nitrogen typically accounts for $60-70 \%$ of total nitrogen excretion $[14,15]$, indicating that more attention should be paid to porcine urinary nitrogen. Theoretically, decreasing the entry of the main nitrogen precursors of urea into the liver is an important strategy for reducing urinary nitrogen. Ammonia $\left(\mathrm{NH}_{3}\right)$, which is a direct nitrogen donor for urea, is mainly derived from the catabolism of amino acids, particularly those that represent a source of metabolic fuel and undergo extensive oxidative metabolism in the portal-drained viscera (PDV; including stomach, small and large intestines, pancreas, spleen, and omental fat) [16, 17]. Although glucose is a primary source of metabolic fuel that can be universally metabolized, large amounts of amino acids are metabolized in the PDV, for example, a large part of all non-essential amino acids (NEAAs) are oxidized by the absorptive epithelial cells (enterocytes) of mammalian small intestines [18-20]; $30-50 \%$ of essential amino acids (EAAs) in the diet may be catabolized by the small intestines in first-pass metabolism [21]. While glucose has little effect on the oxidative metabolism of amino acids, most amino acids, including glutamate and glutamine, can suppress glucose oxidation [22, 23]. Although intestinal mucosal amino acid metabolism is essential for maintaining intestinal integrity and function [24, 25], it should be noted that most amino acids metabolized in the intestines, particularly Gln, Glu, and Asp, are used as metabolic fuel [26] and produce nitrogen precursors for urea synthesis. Therefore, identifying the regulatory measures that promote glucose oxidation in the presence of amino acids is an important step for reducing nitrogen excretion and modifying LP diets.

With the aim of achieving this goal, we previously conducted a series of studies in which we made a number of key observations $[17,27,28]$. First, we found that NEAA insufficiency is a major disadvantage of the existing lowprotein diets [17]. Second, we established that pyruvate, which is critical to energy metabolism $[29,30]$, could potentially replace the role of amino acids as a metabolic fuel and consequently reduce nitrogen excretion in pigs [27]. Third, we revealed that the pyruvate dehydrogenase kinase (PDK)/pyruvate dehydrogenase (PDH) axis is a key target for shifting amino acid oxidation to glucose/ pyruvate metabolism [28]. In addition, we also found that culturing cells in the presence of sodium dichloroacetate (DCA) increased the phosphorylation of PDHA1/ pyruvate dehydrogenase phosphatase 1 (PDP1), inhibited the phosphorylation of PDK1, and promoted increases in the mRNA and protein expression of glucose transporter 1 (GLUT1) and GLUT4 in cells, thereby increasing glucose consumption and reducing amino acid metabolism [28]. DCA, which is an inhibitor of PDK [31], binds to the N-terminal domain of PDK and promotes conformational changes, leading to the inactivation of kinase activity and reactivation of glucose oxidation [32]. DCA has been shown to reverse the Warburg effect of colorectal cancer [33-35], thereby reinstating oxidative phosphorylation. Oral administration has been shown to significantly increase in the activity of the PDH complex and tricarboxylic acid (TCA) cycle, not only in the platelets but also in various human tissues [36]. Previous studies have also indicated that DCA may be used as a metabolic modulator to enhance carbohydrate oxidative metabolism more precisely glucose oxidative metabolism, while reducing amino acid oxidative metabolism, thereby achieving the goal of reducing porcine nitrogen excretion. In addition, DCA is inexpensive, generally recognized as being safe [37-39], and has no detectable bone marrow, hepatic, renal, pulmonary, or cardiac toxicity [39]. Moreover, DCA-loaded mats had minimal effects on physical function after subcutaneous implantation or even attachment to the liver of mice [40].

We therefore hypothesized that DCA would be a suitable dietary additive to reduce nitrogen excretion in pigs by increasing amino acid utilization efficiency. Accordingly, the objective of the present study was to determine the effects of DCA supplementation of a LP diet (in which dietary $\mathrm{CP}$ was reduced by $4.5 \%$ ) on nitrogen excretion and amino acid metabolism in the PDV and liver of pigs.

\section{Materials and methods}

\section{Animal use and care}

All animal procedures complied with the relevant ethical and animal welfare standards and were approved by the ethics committee of Southwest University.

Crossbred pigs (Yorkshire-Landrace sow $\times$ Duroc boar) were obtained from a local commercial swine farm and were reared individually in stainless-steel metabolic cages $(1.8 \mathrm{~m} \times 1.2 \mathrm{~m} \times 0.75 \mathrm{~m})$. All pigs had ad libitum access to fresh water. The room temperature was maintained at approximately $26^{\circ} \mathrm{C}$ (range, $25.4-26.6^{\circ} \mathrm{C}$ ) using thermostatically controlled heaters and exhaust fans.

\section{Assessment of nitrogen balance}

To measure nitrogen excretion, 18 barrows $(40 \pm 1.0 \mathrm{~kg})$ were randomly assigned to receive one of three dietary treatments: $18 \%$ CP (control), 13.5\% CP (LP), and 13.5\% 
CP + $100 \mathrm{mg}$ DCA/kg dry matter (LP-DCA). The control diet was formulated according to the recommendations of the National Research Council [41] and Lys, Met, Thr, and Trp were added to the LP diets (Table 1), making the actual amino acid intake (with the exception of Lys, Met, Thr, and Trp) of pigs in the LP and LP-DCA groups lower than that of pigs in the control group (Table 2). The dose of DCA selected for use in this study was based on that reported in the literature $[38,42]$. The experimental period lasted $14 \mathrm{~d}$, including habituation for the first $7 \mathrm{~d}$ and sample collection for the remainder of the period. The daily feed ( $45 \mathrm{~g} / \mathrm{kg}$ body weight) was provided as two equal meals at 07:00 and 17:00 h. From d 8 to d 14, the feed was supplemented with $0.3 \% \mathrm{TiO}_{2}$ (as a digesta marker). Feces and urine were collected at 08:00, 15:00, and 23:00 $\mathrm{h}$ from $\mathrm{d} 11$ to $\mathrm{d} 14$. The samples were collected according to previously described methods [17]. Briefly, the collected feces (approximately $0.2 \mathrm{~kg}$ per pig per collection) were combined with $10 \%$ sulfuric acid $(10 \mathrm{~mL} / 100 \mathrm{~g}$ feces $)$ and frozen at $-20^{\circ} \mathrm{C}$. All urine samples were collected in plastic bottles, weighed, recorded, and stored at $-20^{\circ} \mathrm{C}$. Five milliliters of $6 \mathrm{~mol} / \mathrm{L} \mathrm{HCl}$ was added daily to each urine collection bottle, thereby preventing evaporation and nitrogen loss. Feed intake was recorded daily during the sample collection period.

At the end of the sample collection period, the urine and feces samples obtained from each pig were pooled per pig, mixed, and divided into subsamples. The fecal subsamples were dried, ground, and passed through a 1-mm screen for nutrient analysis, with all samples being analyzed in duplicate. The dry matter and organic matter content in the diet and feces; the $\mathrm{CP}$ content in the diet, urine, and feces; the amounts of phosphorus and calcium in the diet; and the amounts of titanium in the feces and diet were analyzed according to previously described methods [43, 44]. The energy in the feed, feces, and urine was determined using an adiabatic bomb calorimeter (C5000; IKA Werke GmbH, Staufen im Breisgau, Germany). The energy content of urine was determined after freeze-drying approximately $50 \mathrm{~mL}$ of urine in polyethylene bags. After hydrolysis with 6 $\mathrm{mol} / \mathrm{L}$ at $110^{\circ} \mathrm{C}$, the amounts of amino acids (with the exception of Trp, Cys, and Met) in the feed were measured using an automatic amino acid analyzer (L8900; Hitachi, Tokyo, Japan). The analytical procedures used for Trp, Cys, and Met followed previously described methods [45].

\section{Assessment of nutrient fluxes}

After fasting for $24 \mathrm{~h}, 15$ barrows $(40 \pm 1.0 \mathrm{~kg})$ were surgically catheterized in the carotid artery, hepatic vein, portal vein, and mesenteric vein using polyurethane
Table 1 Ingredients and composition of diets differing in crude protein content (dry matter basis, \%)

\begin{tabular}{|c|c|c|}
\hline \multirow[t]{2}{*}{ Items } & \multicolumn{2}{|l|}{ Diets } \\
\hline & Control & $L P$ \\
\hline \multicolumn{3}{|l|}{ Ingredients } \\
\hline Corn & 61.20 & 74.55 \\
\hline Soybean meal & 25.90 & 12.07 \\
\hline Wheat bran & 7.80 & 7.39 \\
\hline Soybean oil & 2.00 & 2.00 \\
\hline Lys & 0.18 & 0.55 \\
\hline Met & 0.05 & 0.12 \\
\hline Thr & 0.01 & 0.24 \\
\hline Trp & 0.00 & 0.08 \\
\hline Dicalcium phosphate & 0.69 & 0.90 \\
\hline Calcium carbonate & 0.87 & 0.80 \\
\hline Salt & 0.30 & 0.30 \\
\hline $1 \%$ Premix $^{a}$ & 1.00 & 1.00 \\
\hline Total & 100.00 & 100.00 \\
\hline \multicolumn{3}{|l|}{ Composition } \\
\hline Metabolic energy, MJ/kg ${ }^{\mathrm{b}}$ & 13.9 & 13.9 \\
\hline Crude protein ${ }^{c}$ & 18.0 & 13.5 \\
\hline Lys $^{c}$ & 1.11 & 1.12 \\
\hline $\operatorname{Met}^{\mathrm{c}}$ & 0.35 & 0.35 \\
\hline Thr $r^{c}$ & 0.73 & 0.73 \\
\hline $\operatorname{Trp}^{c}$ & 0.22 & 0.22 \\
\hline $\operatorname{Arg}^{c}$ & 1.01 & 0.76 \\
\hline $\mathrm{His}^{\mathrm{c}}$ & 0.44 & 0.33 \\
\hline$\| e^{c}$ & 0.71 & 0.55 \\
\hline Leu $^{c}$ & 1.35 & 1.02 \\
\hline Phe $^{c}$ & 0.79 & 0.61 \\
\hline $\mathrm{Val}^{\mathrm{c}}$ & 0.68 & 0.52 \\
\hline $\operatorname{Pro}^{c}$ & 0.73 & 0.56 \\
\hline$A s x(A s p+A s n)^{c}$ & 1.76 & 1.34 \\
\hline $\operatorname{Ser}^{c}$ & 0.74 & 0.57 \\
\hline $\mathrm{Glx}(\mathrm{Glu}+\mathrm{G} \ln )^{c}$ & 2.95 & 2.23 \\
\hline Gly $^{c}$ & 0.58 & 0.44 \\
\hline $\mathrm{Ala}^{\mathrm{c}}$ & 0.79 & 0.60 \\
\hline Cys $^{c}$ & 0.23 & 0.18 \\
\hline $\operatorname{Tyr}^{c}$ & 0.37 & 0.28 \\
\hline Calcium $^{d}$ & 0.63 & 0.63 \\
\hline Phosphorus $^{d}$ & 0.54 & 0.54 \\
\hline
\end{tabular}

Abbreviations: Control 18.0\% CP, LP 13.5\% CP

a Providing the following per kg diet: Cu (as copper sulfate), $100 \mathrm{mg}$; $\mathrm{Fe}$ (as ferrous sulfate), $100 \mathrm{mg}$; $\mathrm{Zn}$ (as zinc oxide), $120 \mathrm{mg}$; $\mathrm{Mn}$ (as manganese sulfate), $20 \mathrm{mg}$; I (as calcium iodate), $0.3 \mathrm{mg}$; and Se (as sodium selenite), $0.3 \mathrm{mg}$; vitamin $\mathrm{A}, 3,800 \mathrm{IU}$; vitamin $\mathrm{D}_{3}$, $800 \mathrm{IU}$; vitamin $\mathrm{E}, 10 \mathrm{IU}$; vitamin $\mathrm{K}, 1 \mathrm{mg}$; choline, $200 \mathrm{mg}$; pantothenic, $5 \mathrm{mg}$; vitamin $B_{2}, 2 \mathrm{mg}$; folic acid, $0.8 \mathrm{mg}$; niacin, $10 \mathrm{mg}$; vitamin $\mathrm{B}_{1}, 1 \mathrm{mg}$; vitamin $B_{6}, 1 \mathrm{mg}$; biotin, $0.08 \mathrm{mg}$; vitamin $\mathrm{B}_{12}, 0.01 \mathrm{mg}$ ${ }^{b}$ Calculated values

Values for standardized ileal digestible concentrations of amino acids in diets were calculated using standardized ileal digestible coefficients for the various ingredients provided by NRC (2012) [41]

${ }^{\mathrm{d}}$ Analyzed values 
Table 2 The effects of adding sodium dichloroacetate (DCA) to low-protein diets on the dry matter and amino acid intakes of 40-kg pigs in a nitrogen balance experiment

\begin{tabular}{|c|c|c|c|c|c|}
\hline \multirow[t]{2}{*}{ Items } & \multicolumn{3}{|c|}{ Treatments } & \multirow[t]{2}{*}{ SEM } & \multirow[t]{2}{*}{$P$} \\
\hline & Control & LP & LP-DCA & & \\
\hline Intake of feed, $\mathrm{kg}$ & 2.12 & 2.20 & 2.18 & 0.04 & 0.332 \\
\hline \multicolumn{6}{|c|}{ Intakes of amino acids, $\mathrm{g} / \mathrm{d}$} \\
\hline Lys & 24.9 & 24.0 & 23.4 & 0.18 & 0.417 \\
\hline Met & 7.40 & 7.12 & 6.97 & 0.05 & 0.514 \\
\hline Thr & 16.7 & 16.2 & 15.8 & 0.12 & 0.889 \\
\hline Trp & 4.43 & 4.29 & 4.19 & 0.04 & 0.356 \\
\hline Arg & $21.9^{\mathrm{a}}$ & $15.8^{\mathrm{b}}$ & $15.3^{b}$ & 0.13 & $<.001$ \\
\hline His & $9.63^{\mathrm{a}}$ & $7.14^{\mathrm{b}}$ & $6.99^{b}$ & 0.06 & $<.001$ \\
\hline Ile & $15.3^{\mathrm{a}}$ & $11.4^{\mathrm{b}}$ & $11.3^{\mathrm{b}}$ & 0.10 & $<.001$ \\
\hline Leu & $29.3^{\mathrm{a}}$ & $21.5^{\mathrm{b}}$ & $21.1^{b}$ & 0.17 & $<.001$ \\
\hline Phe & $17.1^{\mathrm{a}}$ & $12.8^{\mathrm{b}}$ & $12.6^{\mathrm{b}}$ & 0.11 & $<.001$ \\
\hline Val & $14.8^{\mathrm{a}}$ & $10.8^{b}$ & $10.7^{\mathrm{b}}$ & 0.10 & $<.001$ \\
\hline Pro & $15.9^{\mathrm{a}}$ & $11.7^{\mathrm{b}}$ & $11.5^{\mathrm{b}}$ & 0.10 & $<.001$ \\
\hline Asx (Asp+Asn) & $38.2^{\mathrm{a}}$ & $28.5^{\mathrm{b}}$ & $28.1^{\mathrm{b}}$ & 0.23 & $<.001$ \\
\hline Ser & $16.0^{\mathrm{a}}$ & $11.9^{b}$ & $11.8^{\mathrm{b}}$ & 0.10 & $<.001$ \\
\hline Glx (Glu + Gln) & $64.0^{\mathrm{a}}$ & $47.7^{b}$ & $47.1^{b}$ & 0.39 & $<.001$ \\
\hline Gly & $12.6^{\mathrm{a}}$ & $9.26^{\mathrm{b}}$ & $9.08^{b}$ & 0.07 & $<.001$ \\
\hline Ala & $17.1^{\mathrm{a}}$ & $12.3^{b}$ & $12.2^{\mathrm{b}}$ & 0.11 & $<.001$ \\
\hline Cys & $9.38^{\mathrm{a}}$ & $6.90^{\mathrm{b}}$ & $6.93^{b}$ & 0.06 & $<.001$ \\
\hline Tyr & $8.03^{\mathrm{a}}$ & $6.06^{\mathrm{b}}$ & $5.93^{b}$ & 0.05 & $<.001$ \\
\hline EAAs & $162^{\mathrm{a}}$ & $131^{b}$ & $128^{b}$ & 1.04 & $<.001$ \\
\hline NEAAs & $181^{a}$ & $134^{b}$ & $133^{b}$ & 1.10 & $<.001$ \\
\hline TAAs & $343^{\mathrm{a}}$ & $265^{b}$ & $261^{b}$ & 2.13 & $<.001$ \\
\hline
\end{tabular}

Data are presented as means $(n=6)$

Abbreviations: Control $18.0 \%$ CP, CP Crude protein, DM Dry matter, $E A A s$ Essential amino acids, NEAAs Non-essential amino acids, LP $13.5 \%$ CP, LP-DCA $13.5 \% \mathrm{CP}+100 \mathrm{mg}$ DCA $/ \mathrm{kg}$ DM, SEM Standard error of mean, TAAs Total amino acids

${ }^{a, b}$ Values within a row with different superscripts differ significantly $(P<0.05)$

(2.41 mm OD) under isoflurane anesthesia and sterile conditions according to previously described methods [46]. After surgery, pigs were maintained in metabolism cages for recovery and received an intramuscular injection of penicillin twice daily $\left(1.6 \times 10^{7}\right.$ units $)$ for $7 \mathrm{~d}$. Catheters were flushed daily aseptically with $200 \mathrm{IU}$ of heparinized normal saline to maintain their patency and were protected in pockets attached to a jacket made of size 7 Surgilast (Glenwood Laboratories Canada, Oakville, ON, Canada). Wound Clear Spray (Guangan Animal Health Co., Changsha, Hunan, China) was applied to the sutures and to the exit site of catheters.

One week after surgery (or at the point at which pigs achieved $>80 \%$ of their pre-surgery feed intake for than $2 \mathrm{~d}$ ), the pigs were randomly assigned to one of the three dietary treatments: $18 \% \mathrm{CP}$ (control), $13.5 \% \mathrm{CP}$ (LP), or $13.5 \% \mathrm{CP}+100 \mathrm{mg} \mathrm{DCA} / \mathrm{kg}$ dry matter (LP-DCA). The experiment continued for $7 \mathrm{~d}$, with blood samples collected on the final day. During the experimental period, the feed ( $45 \mathrm{~g} / \mathrm{kg}$ body weight) was divided into three equal portions, provided at 08:00, 14:00, and 20:00 h. On the day of blood sampling, the animals received a priming dose of $p$-aminohippuric acid (PAH) solution (0.75 $\mathrm{mL} / \mathrm{kg} ; 0.14 \mu \mathrm{mol} / \mathrm{mL}$ ) via the mesenteric vein at 07:30 $\mathrm{h}$, followed by a constant infusion of PAH solution at a rate of $3.2 \mathrm{~mL} / \mathrm{kg} / \mathrm{h}$. At 08:30, 10:00, 12:00, 14:30, and $17: 30 \mathrm{~h}, 5 \mathrm{~mL}$ blood samples were collected from the carotid artery, portal vein, and hepatic vein, to which sodium heparin solution $(100 \mathrm{IU} / \mathrm{mL})$ was added as an anticoagulant. The blood samples were immediately placed on ice and centrifuged at $3,000 \times g$ for $10 \mathrm{~min}$ at $4{ }^{\circ} \mathrm{C}$, and the plasma was stored at $-20^{\circ} \mathrm{C}$. The plasma obtained from each site at the five time points was pooled for each pig, and the concentration of $\mathrm{PAH}$ in the plasma was measured following previously described methods [47] with some modification [48]. The hepatic vein plasma flow (HVPF; $\mathrm{mL} / \mathrm{kg} / \mathrm{h}$ ) and the portal vein plasma flow (PVPF; $\mathrm{mL} / \mathrm{kg} / \mathrm{h}$ ) were calculated using the following equations $[17,49]$ :

$$
\begin{aligned}
& \mathrm{HVPF}=C_{\mathrm{i}} \times \mathrm{IR} /\left(\mathrm{PAH}_{\mathrm{hv}}-\mathrm{PAH}_{\mathrm{ca}}\right) \\
& \mathrm{PVPF}=C_{\mathrm{i}} \times \mathrm{IR} /\left(\mathrm{PAH}_{\mathrm{pv}}-\mathrm{PAH}_{\mathrm{ca}}\right)
\end{aligned}
$$

where $C_{\mathrm{i}}$ is the concentration of infused PAH solution $(\mathrm{mg} / \mathrm{mL})$; IR is the infusion rate $(\mathrm{mL} / \mathrm{kg} / \mathrm{h})$ of $\mathrm{PAH}$; and $\mathrm{PAH}_{\mathrm{hv}}, \mathrm{PAH}_{\mathrm{ca}}$, and $\mathrm{PAH}_{\mathrm{pv}}$ are the PAH concentrations $(\mathrm{mg} / \mathrm{mL})$ in the hepatic vein, carotid artery, and portal vein, respectively. The hepatic artery plasma flow (HAPF; $\mathrm{mL} / \mathrm{kg} / \mathrm{h}$ ) was then calculated as follows:

$$
\mathrm{HAPF}=\mathrm{HVPF}-\mathrm{PVPF}
$$

The concentrations of plasma urea and $\mathrm{NH}_{3}$ were measured following previously described procedures [50]. The analysis of fresh plasma $\mathrm{NH}_{3}$ was performed within $2 \mathrm{~h}$ of blood collection. The frozen plasma samples were thawed at $4{ }^{\circ} \mathrm{C}$ and precipitation of the proteins therein was carried out as follows. Briefly, 1 $\mathrm{mL}$ of the sample and $2.5 \mathrm{~mL}$ of $7.5 \% \quad(\mathrm{w} / \mathrm{v})$ trichloroacetic acid solution were mixed thoroughly and centrifuged at $12,000 \times g$ and $4{ }^{\circ} \mathrm{C}$ for $15 \mathrm{~min}$. The supernatant was collected and analyzed for amino acids using an automatic amino acid analyzer (L8900; Hitachi, Tokyo, Japan). The fluxes of plasma amino acids $(\mathrm{mg} / \mathrm{kg} / \mathrm{h}), \mathrm{NH}_{3}(\mu \mathrm{mol} / \mathrm{kg} / \mathrm{h})$, and urea $(\mathrm{mmol} / \mathrm{kg} / \mathrm{h})$ across the carotid artery, portal vein, or hepatic vein were calculated as the concentration of a plasma nitrogen-containing compound in a vein multiplied by the plasma flow across the vein. The PDV balance of a nitrogen-containing compound was calculated as follows: 


\begin{abstract}
PVPF $\times($ the concentration of plasma nitrogen
- containing compound in the portal vein

-the concentration of the corresponding compound in the carotid artery).
\end{abstract}

A positive value means net uptake and a negative value signifies net release. The hepatic balance of nitrogencontaining compound was calculated as follows:

the concentration of nitrogen-containing compound in the hepatic artery $\times$ HAPF + the AA concentration in the portal vein $\times$ PVPF - the AA concentration in the hepatic vein $\times$ HVPF. A positive value indicates that the amount of nitrogen-containing compound leaving the liver is smaller than that entering the liver, whereas a negative value indicates that the amount of nitrogen-containing compound leaving the liver is greater than that entering the liver.

\section{Statistical analysis}

Data were analyzed based on a randomized complete block design considering the pig as the experimental unit. The MIXED procedure of SAS (SAS Institute, Cary, $\mathrm{NC}$, USA) was used to analyze the variables. The fixed effect consisted of dietary treatment (control, LP, and LP-DCA), with the pig as the random component. The model used was as follows:

$$
Y_{i j k}=\mu+T_{i}+L_{i}+A_{j}+E_{i j k}
$$

where $Y_{i j k}$ is the dependent variable, $\mu$ is the overall mean, $T_{i}$ is the dietary treatment, $L_{i}$ is the period effect, $A_{i}$ is the pig effect, and $E_{i j k}$ is the residual error. Differences between treatment means were determined by Tukey multiple comparison tests. Results are reported as means \pm SEM, and $P<0.05$ was considered statistically significant.

Table 3 The effects of adding sodium dichloroacetate (DCA) to low-protein diets on the nitrogen balance and apparent digestibility of other nutrients in 40-kg pigs

\begin{tabular}{|c|c|c|c|c|c|}
\hline \multirow[t]{2}{*}{ Items } & \multicolumn{3}{|c|}{ Treatments } & \multirow[t]{2}{*}{ SEM } & \multirow[t]{2}{*}{$P$} \\
\hline & Control & $L P$ & LP-DCA & & \\
\hline \multicolumn{6}{|l|}{ Nitrogen utilization } \\
\hline Average daily feed intake & 1.60 & 1.66 & 1.66 & 0.07 & 0.543 \\
\hline Intake of nitrogen, $\mathrm{g} / \mathrm{d}$ & $46.0^{\mathrm{a}}$ & $35.8^{\mathrm{b}}$ & $35.9^{b}$ & 0.54 & $<.001$ \\
\hline Urinary nitrogen, g/d & $13.6^{\mathrm{a}}$ & $10.4^{\mathrm{b}}$ & $7.52^{c}$ & 0.17 & $<.001$ \\
\hline Fecal nitrogen, g/d & $9.03^{\mathrm{a}}$ & $5.87^{\mathrm{b}}$ & $5.54^{\mathrm{b}}$ & 0.11 & $<.001$ \\
\hline Total nitrogen excretion, $\mathrm{g} / \mathrm{d}$ & $22.6^{\mathrm{a}}$ & $16.3^{b}$ & $13.1^{c}$ & 0.26 & $<.001$ \\
\hline Retention of nitrogen, $\mathrm{g} / \mathrm{d}$ & $23.4^{\mathrm{a}}$ & $19.5^{\mathrm{b}}$ & $22.8^{\mathrm{a}}$ & 0.35 & $<.001$ \\
\hline Urinary nitrogen/intake of nitrogen, \% & $29.6^{\mathrm{a}}$ & $29.1^{\mathrm{a}}$ & $20.9^{b}$ & 0.28 & $<.001$ \\
\hline Fecal nitrogen/intake of nitrogen, $\%$ & $19.6^{\mathrm{a}}$ & $16.4^{\mathrm{b}}$ & $15.4^{\mathrm{b}}$ & 0.20 & $<.001$ \\
\hline Total nitrogen excretion/intake of nitrogen, \% & $49.2^{\mathrm{a}}$ & $45.4^{\mathrm{b}}$ & $36.4^{c}$ & 0.36 & $<.001$ \\
\hline Urinary nitrogen/total nitrogen excretion, \% & $60.2^{\mathrm{ab}}$ & $63.9^{\mathrm{a}}$ & $57.6^{\mathrm{b}}$ & 0.38 & $<.001$ \\
\hline Fecal nitrogen/total nitrogen excretion, \% & $39.9^{\mathrm{b}}$ & $36.1^{c}$ & $42.4^{\mathrm{a}}$ & 0.38 & $<.001$ \\
\hline Retention of nitrogen/intake of nitrogen, $\%$ & $50.8^{c}$ & $54.6^{\mathrm{b}}$ & $63.6^{\mathrm{a}}$ & 0.36 & $<.001$ \\
\hline \multicolumn{6}{|l|}{ Other nutrient utilization, \% } \\
\hline DM digestibility & $75.3^{b}$ & $77.1^{\mathrm{ab}}$ & $79.5^{\mathrm{a}}$ & 0.48 & $<.001$ \\
\hline Organic matter digestibility & $74.9^{\mathrm{b}}$ & $77.9^{\mathrm{ab}}$ & $79.4^{\mathrm{a}}$ & 0.40 & $<.001$ \\
\hline Digestive energy digestibility & $70.8^{\mathrm{b}}$ & $73.4^{\mathrm{ab}}$ & $75.8^{\mathrm{a}}$ & 0.57 & $<.001$ \\
\hline Metabolic energy/digestive energy ratio & $84.1^{\mathrm{b}}$ & $87.2^{\mathrm{ab}}$ & $90.2^{\mathrm{a}}$ & 0.44 & $<.001$ \\
\hline
\end{tabular}

Data are presented as means $(n=6)$

Abbreviations: Control, 18.0\% CP, CP Crude protein, DM Dry matter, LP 13.5\% CP, LP-DCA 13.5\% CP + $100 \mathrm{mg} D C A / \mathrm{kg} D M, S E M$ Standard error of mean

$a, b, c$ Values within a row with different superscripts differ significantly $(P<0.05)$ 


\section{Results}

\section{Nitrogen balance}

As shown in Table 3, LP diets (LP and LP-DCA) reduced urinary nitrogen excretion, fecal nitrogen excretion, and total nitrogen excretion in pigs $(P<0.05)$. Compared with the control and LP-DCA diets, the LP diet reduced the retention of nitrogen in pigs $(P<0.05)$. Furthermore, we found that the digestive energy digestibility and metabolic energy/digestive energy ratio of pigs in the LP-DCA group were both higher than those of pigs in the control group $(P<0.05)$.

\section{AA metabolism in the PDV and liver}

As shown in Table 4, with the exception of Lys, Trp, and urea, the concentrations of plasma nitrogenous compounds in the portal vein of pigs fed the LP diet were lower than those of pigs fed the control diet $(P<$ 0.05). The concentrations of plasma Met, Arg, His, Ile,
Phe, Val, Pro, Ser, Gly, Ala, and EAAs in the hepatic vein of pigs fed the LP were lower than those of pigs fed the control diet $(P<0.05)$. Similarly, the concentrations of plasma Gly, Ala, and $\mathrm{NH}_{3}$ in the portal vein and those of plasma Gly and Ala in the hepatic vein of pigs fed the LP-DCA diet were lower than those of pigs fed the control diet $(P<0.05)$. Furthermore, the concentrations of plasma Thr, Pro, Ser, and Gln in the portal vein and those of plasma Met, Arg, His, Ile, Val, Pro, and EAAs in the hepatic vein of pigs fed the LP diet were lower than those of pigs fed the LP-DCA diet $(P<0.05)$.

As shown in Table 5, plasma flow across the hepatic artery of pigs fed the LP diet was lower than that of pigs in the control group $(P<0.05)$. However, there were no significant differences in plasma flow across the portal and hepatic veins in pigs among the three groups $(P>$ 0.05). The fluxes of plasma nitrogenous compounds across the portal vein (with the exception of Lys, Asn, and urea) and the fluxes of plasma nitrogen-compounds

Table 4 The effects of adding sodium dichloroacetate (DCA) to low-protein diets on the concentrations of amino acids (mg/dL), $\mathrm{NH}_{3}(\mu \mathrm{mol} / \mathrm{L})$, and urea (mmol/L) in the portal vein, hepatic artery, and hepatic vein of 40-kg pigs

\begin{tabular}{|c|c|c|c|c|c|c|c|c|c|c|c|c|c|c|c|}
\hline \multirow[t]{2}{*}{ Items } & \multicolumn{3}{|c|}{ Portal vein } & \multirow[t]{2}{*}{ SEM } & \multirow[t]{2}{*}{$P$} & \multicolumn{3}{|c|}{ Hepatic artery } & \multirow[t]{2}{*}{ SEM } & \multirow[t]{2}{*}{ P } & \multicolumn{3}{|c|}{ Hepatic vein } & \multirow[t]{2}{*}{ SEM } & \multirow[t]{2}{*}{$P$} \\
\hline & Control & LP & LP-DCA & & & Control & LP & LP-DCA & & & Control & LP & LP-DCA & & \\
\hline Lys & 3.30 & 2.93 & 3.15 & 0.07 & 0.076 & 2.42 & 2.14 & 2.32 & 0.06 & 0.071 & 2.88 & 2.57 & 2.87 & 0.08 & 0.058 \\
\hline Met & $1.39^{a}$ & $1.18^{\mathrm{b}}$ & $1.32^{a b}$ & 0.03 & 0.023 & $1.00^{a}$ & $0.86^{b}$ & $0.96^{\mathrm{ab}}$ & 0.03 & 0.049 & $1.22^{\mathrm{a}}$ & $1.03^{b}$ & $1.20^{\mathrm{a}}$ & 0.03 & 0.012 \\
\hline Thr & $3.97^{\mathrm{a}}$ & $3.55^{\mathrm{b}}$ & $3.86^{\mathrm{a}}$ & 0.09 & 0.028 & 3.22 & 2.91 & 3.15 & 0.09 & 0.100 & 3.65 & 3.25 & 3.63 & 0.11 & 0.054 \\
\hline Trp & 0.64 & 0.56 & 0.59 & 0.01 & 0.068 & 0.45 & 0.40 & 0.44 & 0.01 & 0.077 & 0.50 & 0.46 & 0.51 & 0.01 & 0.053 \\
\hline Arg & $2.95^{a}$ & $2.56^{b}$ & $2.80^{a b}$ & 0.06 & 0.024 & 2.21 & 1.98 & 2.11 & 0.06 & 0.130 & $2.55^{\mathrm{a}}$ & $2.21^{b}$ & $2.53^{a}$ & 0.06 & 0.026 \\
\hline His & $2.08^{a}$ & $1.74^{\mathrm{b}}$ & $1.94^{\mathrm{ab}}$ & 0.04 & 0.014 & 1.63 & 1.43 & 1.51 & 0.04 & 0.087 & $1.83^{\mathrm{a}}$ & $1.53^{b}$ & $1.78^{\mathrm{a}}$ & 0.04 & 0.009 \\
\hline lle & $2.32^{a}$ & $1.97^{\mathrm{b}}$ & $2.16^{\mathrm{ab}}$ & 0.08 & 0.026 & $1.51^{\mathrm{a}}$ & $1.30^{\mathrm{b}}$ & $1.40^{\mathrm{ab}}$ & 0.04 & 0.038 & $1.98^{\mathrm{a}}$ & $1.69^{b}$ & $1.93^{\mathrm{a}}$ & 0.05 & 0.013 \\
\hline Leu & $3.48^{a}$ & $3.07^{b}$ & $3.29^{\mathrm{ab}}$ & 0.07 & 0.024 & 2.50 & 2.26 & 2.41 & 0.07 & 0.157 & 3.12 & 2.79 & 3.05 & 0.08 & 0.057 \\
\hline Phe & $2.77^{\mathrm{a}}$ & $2.37^{b}$ & $2.60^{\mathrm{ab}}$ & 0.06 & 0.018 & 1.99 & 1.78 & 1.89 & 0.05 & 0.136 & $2.45^{a}$ & $2.11^{b}$ & $2.38^{\mathrm{ab}}$ & 0.06 & 0.030 \\
\hline Val & $2.22^{a}$ & $1.93^{b}$ & $2.12^{a b}$ & 0.06 & 0.024 & 1.86 & 1.64 & 1.79 & 0.05 & 0.092 & $2.04^{a}$ & $1.78^{b}$ & $2.00^{a}$ & 0.05 & 0.040 \\
\hline Pro & $1.86^{\mathrm{a}}$ & $1.54^{b}$ & $1.78^{a}$ & 0.04 & 0.002 & 1.44 & 1.28 & 1.41 & 0.04 & 0.143 & $1.60^{a}$ & $1.37^{b}$ & $1.59^{a}$ & 0.04 & 0.017 \\
\hline Asn & $3.30^{a}$ & $2.94^{b}$ & $3.16^{a b}$ & 0.07 & 0.046 & 2.81 & 2.55 & 2.72 & 0.07 & 0.167 & 3.06 & 2.78 & 2.97 & 0.07 & 0.116 \\
\hline Ser & $2.15^{a}$ & $1.66^{b}$ & $2.01^{a}$ & 0.04 & $<.001$ & $1.86^{\mathrm{a}}$ & $1.53^{b}$ & $1.78^{a}$ & 0.05 & 0.004 & $2.04^{a}$ & $1.72^{b}$ & $1.94^{\mathrm{ab}}$ & 0.05 & 0.019 \\
\hline Gln & $4.52^{a}$ & $3.94^{b}$ & $4.35^{\mathrm{a}}$ & 0.09 & 0.008 & 4.87 & 4.57 & 4.77 & 0.13 & 0.429 & 5.32 & 5.10 & 5.25 & 0.13 & 0.780 \\
\hline Gly & $5.56^{a}$ & $4.95^{b}$ & $4.57^{b}$ & 0.11 & $<.001$ & 3.35 & 3.22 & 3.25 & 0.09 & 0.660 & $4.39^{a}$ & $3.98^{b}$ & $3.93^{b}$ & 0.10 & 0.018 \\
\hline Ala & $5.88^{a}$ & $5.10^{b}$ & $4.69^{b}$ & 0.11 & $<.001$ & 3.50 & 3.32 & 3.30 & 0.09 & 0.300 & $4.59^{a}$ & $4.07^{b}$ & $3.92^{b}$ & 0.11 & 0.007 \\
\hline Cys & $1.94^{\mathrm{a}}$ & $1.66^{\mathrm{b}}$ & $1.82^{a b}$ & 0.06 & 0.016 & $1.63^{a}$ & $1.39^{b}$ & $1.52^{\mathrm{ab}}$ & 0.04 & 0.016 & 1.84 & 1.63 & 1.79 & 0.04 & 0.219 \\
\hline Tyr & $2.29^{a}$ & $1.98^{b}$ & $2.18^{a b}$ & 0.07 & 0.016 & 2.03 & 1.82 & 1.95 & 0.05 & 0.173 & 2.13 & 1.90 & 2.10 & 0.05 & 0.175 \\
\hline EAAs & $25.1^{a}$ & $21.9^{b}$ & $24.1^{\mathrm{ab}}$ & 0.63 & 0.017 & 18.8 & 16.7 & 18.0 & 0.49 & 0.103 & $22.3^{a}$ & $19.5^{b}$ & $21.9^{a}$ & 0.54 & 0.037 \\
\hline NEAAs & $27.5^{\mathrm{a}}$ & $23.6^{b}$ & $24.9^{\mathrm{ab}}$ & 0.66 & 0.013 & 21.5 & 19.7 & 20.7 & 0.57 & 0.257 & 25.0 & 22.6 & 23.5 & 0.59 & 0.103 \\
\hline TAAs & $52.6^{a}$ & $45.5^{b}$ & $49.0^{\mathrm{ab}}$ & 1.19 & 0.018 & 40.3 & 36.35 & 38.7 & 1.06 & 0.166 & 47.2 & 42.0 & 45.4 & 1.13 & 0.075 \\
\hline $\mathrm{NH}_{3}$ & $93.7^{a}$ & $80.2^{b}$ & $69.7^{c}$ & 2.42 & $<.001$ & 44.5 & 45.0 & 41.4 & 1.26 & 0.292 & 49.3 & 48.0 & 44.0 & 1.38 & 0.083 \\
\hline Urea & 7.70 & 7.68 & 7.12 & 0.17 & 0.722 & 7.93 & 7.90 & 6.91 & 0.22 & 0.310 & 8.76 & 8.48 & 7.63 & 0.21 & 0.163 \\
\hline
\end{tabular}

Data are presented as means $(n=5)$

Abbreviations: CP Crude protein, DM Dry matter, EAAs Essential amino acids, NEAAs Non-essential amino acids, LP 13.5\% CP, LP-DCA $13.5 \%$ CP + 100 mg DCA/kg DM, SEM Standard error of mean, TAAs Total amino acids

$\mathrm{a}, \mathrm{b}, \mathrm{c}$ Values within a row with different superscripts differ significantly $(P<0.05)$ 
Table 5 The effects of adding sodium dichloroacetate (DCA) to low-protein diets on the fluxes of plasma (mL/ $\mathrm{kg} / \mathrm{h}$ ), amino acids $(\mathrm{mg} / \mathrm{kg} / \mathrm{h}), \mathrm{NH}_{3}(\mu \mathrm{mol} / \mathrm{kg} / \mathrm{h})$, and urea $(\mathrm{mmol} / \mathrm{kg} / \mathrm{h})$ across the portal vein, hepatic artery, and hepatic vein of 40-kg pigs

\begin{tabular}{|c|c|c|c|c|c|c|c|c|c|c|c|c|c|c|c|}
\hline \multirow[t]{2}{*}{ Items } & \multicolumn{3}{|c|}{ Portal vein } & \multirow[t]{2}{*}{ SEM } & \multirow[t]{2}{*}{$P$} & \multicolumn{3}{|c|}{ Hepatic artery } & \multirow[t]{2}{*}{ SEM } & \multirow[t]{2}{*}{ P } & \multicolumn{3}{|c|}{ Hepatic vein } & \multirow[t]{2}{*}{ SEM } & \multirow[t]{2}{*}{ P } \\
\hline & Control & LP & LP-DCA & & & Control & $L P$ & LP-DCA & & & Control & $L P$ & LP-DCA & & \\
\hline Plasma & 1614 & 1627 & 1659 & 35.6 & 0.878 & $409^{a}$ & $346^{b}$ & $404^{a}$ & 13.9 & 0.004 & 2023 & 1973 & 2063 & 51.3 & 0.330 \\
\hline Lys & 53.4 & 47.5 & 52.1 & 1.25 & 0.060 & $9.88^{\mathrm{a}}$ & $7.59^{b}$ & $9.36^{\mathrm{a}}$ & 0.23 & $<.001$ & $58.4^{\mathrm{a}}$ & $50.8^{b}$ & $58.9^{\mathrm{a}}$ & 2.58 & 0.028 \\
\hline Met & $22.5^{\mathrm{a}}$ & $19.1^{b}$ & $21.7^{\mathrm{a}}$ & 0.53 & 0.024 & $4.08^{\mathrm{a}}$ & $3.05^{\mathrm{b}}$ & $3.86^{\mathrm{a}}$ & 0.09 & $<.001$ & $24.6^{\mathrm{a}}$ & $20.5^{b}$ & $24.6^{\mathrm{a}}$ & 0.99 & $<.001$ \\
\hline Thr & $64.5^{\mathrm{a}}$ & $57.5^{b}$ & $63.9^{\mathrm{a}}$ & 1.52 & 0.037 & $13.2^{\mathrm{a}}$ & $10.3^{\mathrm{b}}$ & $12.7^{\mathrm{a}}$ & 0.32 & $<.001$ & $73.8^{\mathrm{a}}$ & $64.4^{\mathrm{b}}$ & $74.6^{\mathrm{a}}$ & 3.21 & 0.030 \\
\hline Trp & $10.4^{\mathrm{a}}$ & $9.02^{b}$ & $9.84^{\mathrm{ab}}$ & 0.23 & 0.045 & $1.84^{\mathrm{a}}$ & $1.42^{\mathrm{b}}$ & $1.76^{\mathrm{a}}$ & 0.05 & $<.001$ & $10.2^{\mathrm{a}}$ & $9.03^{b}$ & $10.3^{\mathrm{a}}$ & 0.48 & 0.040 \\
\hline Arg & $47.6^{a}$ & $41.5^{\mathrm{b}}$ & $46.3^{\mathrm{a}}$ & 1.10 & 0.023 & $9.03^{\mathrm{a}}$ & $7.02^{\mathrm{b}}$ & $8.54^{a}$ & 0.23 & $<.001$ & $51.6^{\mathrm{a}}$ & $43.8^{\mathrm{b}}$ & $51.9^{a}$ & 2.42 & 0.020 \\
\hline His & $33.6^{\mathrm{a}}$ & $28.3^{b}$ & $32.0^{\mathrm{a}}$ & 0.77 & 0.007 & $6.60^{\mathrm{a}}$ & $5.07^{b}$ & $6.11^{a}$ & 0.17 & $<.001$ & $37.0^{\mathrm{a}}$ & $30.3^{b}$ & $36.6^{a}$ & 1.76 & $<.00$ \\
\hline lle & $37.5^{\mathrm{a}}$ & $31.9^{b}$ & $35.7^{\mathrm{ab}}$ & 0.86 & 0.013 & $6.16^{\mathrm{a}}$ & $4.62^{b}$ & $5.64^{a}$ & 0.18 & $<.001$ & $40.0^{\mathrm{a}}$ & $33.5^{\mathrm{b}}$ & $39.6^{\mathrm{a}}$ & 1.70 & $<.00$ \\
\hline Leu & $56.3^{\mathrm{a}}$ & $49.9^{b}$ & $54.5^{\mathrm{ab}}$ & 1.29 & 0.040 & $10.2^{\mathrm{a}}$ & $8.01^{\mathrm{b}}$ & $9.73^{\mathrm{a}}$ & 0.26 & $<.001$ & $63.3^{\mathrm{a}}$ & $55.1^{b}$ & $62.6^{\mathrm{ab}}$ & 2.72 & 0.047 \\
\hline Phe & $44.7^{a}$ & $38.4^{b}$ & $42.7^{\mathrm{ab}}$ & 1.02 & 0.014 & $8.15^{\mathrm{a}}$ & $6.32^{b}$ & $7.63^{\mathrm{a}}$ & 0.20 & $<.001$ & $49.6^{\mathrm{a}}$ & $41.8^{\mathrm{b}}$ & $48.9^{a}$ & 2.10 & 0.021 \\
\hline Val & $35.9^{\mathrm{a}}$ & $31.4^{b}$ & $35.1^{\mathrm{ab}}$ & 0.84 & 0.040 & $7.60^{\mathrm{a}}$ & $5.83^{b}$ & $7.24^{\mathrm{a}}$ & 0.18 & $<.001$ & $41.3^{\mathrm{a}}$ & $35.2^{\mathrm{b}}$ & $41.1^{\mathrm{a}}$ & 2.99 & 0.031 \\
\hline Pro & $30.1^{a}$ & $25.0^{\mathrm{b}}$ & $29.5^{\mathrm{a}}$ & 0.69 & 0.004 & $5.90^{\mathrm{a}}$ & $4.55^{\mathrm{b}}$ & $5.69^{a}$ & 0.14 & $<.001$ & $32.5^{\mathrm{a}}$ & $27.1^{\mathrm{b}}$ & $32.7^{\mathrm{a}}$ & 2.09 & $<.001$ \\
\hline Asn & 53.3 & 47.6 & 52.3 & 1.25 & 0.068 & $11.5^{\mathrm{a}}$ & $9.03^{b}$ & $11.0^{\mathrm{a}}$ & 0.27 & $<.001$ & 61.9 & 55.0 & 61.0 & 0.96 & 0.087 \\
\hline Ser & $34.7^{\mathrm{a}}$ & $26.9^{b}$ & $33.2^{\mathrm{a}}$ & 0.80 & $<.001$ & $7.61^{\mathrm{a}}$ & $5.42^{\mathrm{b}}$ & $7.17^{\mathrm{a}}$ & 0.17 & $<.001$ & $41.3^{\mathrm{a}}$ & $34.1^{b}$ & $39.9^{\mathrm{a}}$ & 1.65 & 0.015 \\
\hline Gln & $73.0^{\mathrm{a}}$ & $63.9^{b}$ & $71.9^{\mathrm{a}}$ & 1.70 & 0.012 & $19.9^{\mathrm{a}}$ & $16.2^{b}$ & $19.3^{\mathrm{a}}$ & 0.48 & $<.001$ & 108 & 101 & 108 & 4.62 & 0.707 \\
\hline Gly & $89.8^{\mathrm{a}}$ & $80.2^{b}$ & $75.6^{b}$ & 1.97 & 0.001 & $13.8^{\mathrm{a}}$ & $11.4^{b}$ & $13.1^{\mathrm{ab}}$ & 0.38 & 0.018 & $89.0^{\mathrm{a}}$ & $78.7^{b}$ & $80.6^{b}$ & 3.80 & 0.021 \\
\hline Ala & $95.0^{\mathrm{a}}$ & $82.6^{b}$ & $77.7^{\mathrm{b}}$ & 2.07 & $<.001$ & $14.3^{\mathrm{a}}$ & $11.8^{\mathrm{b}}$ & $13.3^{\mathrm{ab}}$ & 0.42 & 0.028 & $92.8^{\mathrm{a}}$ & $80.5^{b}$ & $80.9^{b}$ & 3.92 & 0.008 \\
\hline Cys & $31.3^{\mathrm{a}}$ & $26.8^{b}$ & $30.1^{\mathrm{ab}}$ & 0.72 & 0.027 & $6.71^{\mathrm{a}}$ & $4.92^{\mathrm{b}}$ & $6.14^{b}$ & 0.17 & $<.001$ & $36.8^{\mathrm{a}}$ & $32.3^{b}$ & $35.9^{\mathrm{ab}}$ & 1.52 & 0.025 \\
\hline Tyr & $37.1^{\mathrm{a}}$ & $32.2^{b}$ & $36.2^{\mathrm{a}}$ & 0.86 & 0.028 & $8.26^{\mathrm{a}}$ & $6.45^{\mathrm{b}}$ & $7.87^{\mathrm{a}}$ & 0.18 & $<.001$ & 43.1 & 37.7 & 43.2 & 1.94 & 0.150 \\
\hline EAAs & $406^{\mathrm{a}}$ & $354^{b}$ & $393^{\mathrm{ab}}$ & 9.39 & 0.029 & $76.8^{\mathrm{a}}$ & $59.3^{b}$ & $72.6^{a}$ & 1.92 & $<.001$ & $450^{a}$ & $384^{b}$ & $449^{a}$ & 22.5 & 0.023 \\
\hline NEAAs & $444^{\mathrm{a}}$ & $383^{b}$ & $408^{\mathrm{ab}}$ & 10.0 & 0.019 & $88.0^{\mathrm{a}}$ & $69.8^{\mathrm{b}}$ & $83.5^{\mathrm{a}}$ & 2.58 & $<.001$ & $505^{a}$ & $446^{\mathrm{b}}$ & $482^{\mathrm{ab}}$ & 17.0 & 0.046 \\
\hline TAAs & $850^{a}$ & $737^{b}$ & $801^{a b}$ & 19.4 & 0.018 & $165^{\mathrm{a}}$ & $129^{b}$ & $156^{a}$ & 3.93 & $<.001$ & $955^{a}$ & $831^{b}$ & $931^{a}$ & 36.5 & $<.001$ \\
\hline $\mathrm{NH}_{3}$ & $151^{a}$ & $130^{b}$ & $113^{c}$ & 3.23 & $<.001$ & $18.4^{\mathrm{a}}$ & $18.6^{a}$ & $16.7^{b}$ & 0.54 & 0.034 & 99.9 & 97.4 & 89.3 & 2.74 & 0.098 \\
\hline Urea & 124 & 125 & 117 & 2.94 & 0.908 & $33.4^{\mathrm{a}}$ & $27.3^{b}$ & $27.9^{b}$ & 0.84 & 0.015 & $177^{a}$ & $167^{\mathrm{ab}}$ & $157^{\mathrm{b}}$ & 5.53 & 0.021 \\
\hline
\end{tabular}

Data are presented as means $(n=5)$

Abbreviations: Control 18.0\% CP, CP Crude protein, DM Dry matter, EAAs Essential amino acids, NEAAs Non-essential amino acids, $L P$ 13.5\% CP, LP-DCA $13.5 \%$ CP + $100 \mathrm{mg}$ DCA $/ \mathrm{kg}$ DM, SEM Standard error of mean, TAAs Total amino acids

$a, b, c$ Values within a row with different superscripts differ significantly $(P<0.05)$

across the hepatic vein (with the exception of Asn, Gln, Tyr, $\mathrm{NH}_{3}$, and urea) were lower in pigs fed the LP diet than those of pigs fed the control diet $(P<0.05)$. The fluxes of plasma Gly, Ala, and $\mathrm{NH}_{3}$ across the portal vein and the fluxes of plasma Gly, Ala, and urea across the hepatic vein of pigs fed the LP-DCA diet were lower than those of pigs fed the control diet $(P<0.05)$. Furthermore, the fluxes of plasma Met, Thr, Arg, His, Pro, Ser, Gln, and Tyr across the portal vein and the fluxes of plasma nitrogenous compounds across the hepatic vein of pigs fed the LP diet (with the exception of Leu, Asn, Gln, Gly, Ala, Cys, NEAAs, $\mathrm{NH}_{3}$, and urea) were lower than those of pigs fed the LP-DCA diet $(P<0.05)$.

Compared with the control diet, the LP diet reduced the net release of all nitrogenous compounds (with exception of Lys and Cys) into the portal vein $(P<0.05)$; the LPDCA diet reduced the net release of Trp, Gly, Ala,
NEAAs, total amino acids (TAAs), and $\mathrm{NH}_{3}$ into the portal vein $(P<0.05)$ (Table 6). Moreover, we observed that the net release of Met, Thr, Arg, His, Ile, Leu, Phe, Val, Pro, Asn, Ser, Gln, Tyr, EAAs, TAAs, and $\mathrm{NH}_{3}$ to the portal vein of pigs fed the LP-DCA diet was higher than that of pigs fed the LP $(P<0.05)$. The net release of Gly, Ala, and $\mathrm{NH}_{3}$ to the portal vein of pigs fed the LP-DCA diet was lower than that of pigs fed the LP diet $(P<0.05)$.

Compared with pigs fed the control diet, those fed the LP diet showed reduced metabolism of Met, Trp, Ile, Pro, Asn, Se, Gln, Gly, Ala, Cys, Tyr, EAAs, NEAAs, TAAs, and $\mathrm{NH}_{3}$, as well as a reduction in the production of urea in the liver $(P<0.05)$ (Table 7$)$. Similarly, relative to the pigs in the control group, pigs in the LP-DCA group showed reduced metabolism of Lys, Met, Thr, Trp, Arg, His, Ile, Leu, Phe, Val, Ser, Gly, Ala, Cys, Tyr, EAAs, NEAAs, TAAs, and $\mathrm{NH}_{3}$ and lower production of urea in 
Table 6 The effects of adding sodium dichloroacetate (DCA) to low-protein diets on the portal-drained viscera balance of amino acids $(\mathrm{mg} / \mathrm{kg} / \mathrm{h})$ and $\mathrm{NH}_{3}(\mu \mathrm{mol} / \mathrm{kg} / \mathrm{h})$ in pigs ${ }^{*}$

\begin{tabular}{|c|c|c|c|c|c|}
\hline \multirow[t]{2}{*}{ Items } & \multicolumn{3}{|c|}{ Treatments } & \multirow[t]{2}{*}{ SEM } & \multirow[t]{2}{*}{ P } \\
\hline & Control & $L P$ & LP-DCA & & \\
\hline Lys & 14.3 & 12.9 & 14.2 & 0.29 & 0.087 \\
\hline Met & $6.36^{\mathrm{a}}$ & $5.16^{b}$ & $6.16^{\mathrm{a}}$ & 0.12 & 0.005 \\
\hline Thr & $12.2^{\mathrm{a}}$ & $10.4^{\mathrm{b}}$ & $12.3^{\mathrm{a}}$ & 0.32 & 0.013 \\
\hline Trp & $3.12^{\mathrm{a}}$ & $2.56^{\mathrm{b}}$ & $2.70^{b}$ & 0.05 & 0.031 \\
\hline Arg & $11.9^{\mathrm{a}}$ & $9.44^{\mathrm{b}}$ & $11.8^{\mathrm{a}}$ & 0.25 & $<.001$ \\
\hline His & $7.47^{\mathrm{a}}$ & $5.06^{b}$ & $7.31^{\mathrm{a}}$ & 0.17 & $<.001$ \\
\hline lle & $13.2^{\mathrm{a}}$ & $10.8^{b}$ & $13.0^{\mathrm{a}}$ & 0.25 & $<.001$ \\
\hline Leu & $15.9^{\mathrm{a}}$ & $13.2^{b}$ & $15.1^{\mathrm{a}}$ & 0.31 & 0.001 \\
\hline Phe & $12.5^{\mathrm{a}}$ & $9.57^{\mathrm{b}}$ & $11.9^{\mathrm{a}}$ & 0.24 & $<.001$ \\
\hline Val & $5.83^{\mathrm{a}}$ & $4.70^{b}$ & $5.78^{\mathrm{a}}$ & 0.18 & 0.049 \\
\hline Pro & $6.72^{\mathrm{a}}$ & $4.20^{\mathrm{b}}$ & $6.42^{\mathrm{a}}$ & 0.15 & $<.001$ \\
\hline Asn & $7.80^{\mathrm{a}}$ & $6.37^{b}$ & $7.79^{\mathrm{a}}$ & 0.27 & 0.049 \\
\hline Ser & $4.65^{\mathrm{a}}$ & $2.19^{b}$ & $4.14^{\mathrm{a}}$ & 0.18 & $<.001$ \\
\hline Gln & $-5.67^{a}$ & $-10.3^{b}$ & $-6.19^{a}$ & 0.69 & 0.002 \\
\hline Gly & $35.4^{\mathrm{a}}$ & $28.2^{b}$ & $22.6^{c}$ & 0.57 & $<.001$ \\
\hline Ala & $38.4^{\mathrm{a}}$ & $28.8^{b}$ & $23.8^{c}$ & 0.60 & $<.001$ \\
\hline Cys & 4.74 & 4.20 & 4.86 & 0.15 & 0.176 \\
\hline Tyr & $4.41^{a}$ & $2.64^{b}$ & $4.24^{\mathrm{a}}$ & 0.20 & 0.001 \\
\hline EAAs & $103^{\mathrm{a}}$ & $83.8^{b}$ & $100^{a}$ & 2.13 & $<.001$ \\
\hline NEAAs & $96.5^{\mathrm{a}}$ & $66.3^{b}$ & $67.7^{b}$ & 2.10 & $<.001$ \\
\hline TAAs & $199^{a}$ & $150^{c}$ & $168^{b}$ & 4.20 & $<.001$ \\
\hline $\mathrm{NH}_{3}$ & $79.5^{\mathrm{a}}$ & $56.8^{b}$ & $45.7^{c}$ & 1.46 & $<.001$ \\
\hline \multicolumn{6}{|c|}{$\begin{array}{l}\text { Abbreviations: Control } 18.0 \% \text { CP, CP Crude protein, DM Dry matter, EAAs } \\
\text { Essential amino acids, NEAsA Non-essential amino acids, LP 13.5\% CP, LP-DCA } \\
13.5 \% \mathrm{CP}+100 \mathrm{mg} \text { DCA/kg DM, SEM Standard error of mean, TAAs Total } \\
\text { amino acids } \\
\text { "A positive value means the amount of nitrogen-containing compound } \\
\text { entering the portal vein is greater than that entering the portal-drained } \\
\text { viscera through the artery; a negative value means the amount of nitrogen- } \\
\text { containing compound entering the portal vein is less than that entering the } \\
\text { portal-drained viscera through the artery } \\
\text { a,b, } \mathrm{V} \text { Values within a row with different superscripts differ significantly }(P<0.05)\end{array}$} \\
\hline
\end{tabular}

the liver $(P<0.05)$. Pigs fed the LP-DCA diet showed reduced metabolism of Lys, Met, Thr, Arg, His, Ile, Leu, Phe, Val, Gly, Ala, EAAs, TAAs, and $\mathrm{NH}_{3}$ and reduced production of urea in the liver relative to those fed the LP $\operatorname{diet}(P<0.05)$. The metabolism of Ser, Glu, Cys, Tyr, NEAAs in the liver of pigs fed the LP-DCA diet was higher than that of pigs fed the LP diet $(P<0.05)$.

\section{Discussion}

\section{Nitrogen balance}

In this study, we found that the provision of a LP diet, regardless of whether it was supplemented with DCA, resulted in reduced nitrogen excretion by pigs. Specifically, compared with pigs in the control group, those in the LP
Table 7 The effects of adding sodium dichloroacetate (DCA) to low-protein diets on the hepatic balance of AAs (mg/kg/h), $\mathrm{NH}_{3}$ $(\mu \mathrm{mol} / \mathrm{kg} / \mathrm{h})$, and urea $(\mathrm{mmol} / \mathrm{kg} / \mathrm{h})$ in pigs ${ }^{*}$

\begin{tabular}{|c|c|c|c|c|c|}
\hline \multirow[t]{2}{*}{ Items } & \multicolumn{3}{|c|}{ Treatments } & \multirow[t]{2}{*}{ SEM } & \multirow[t]{2}{*}{ P } \\
\hline & Control & LP & LP-DCA & & \\
\hline Lys & $4.90^{\mathrm{a}}$ & $4.48^{\mathrm{a}}$ & $2.94^{b}$ & 0.09 & $<.001$ \\
\hline Met & $1.97^{\mathrm{a}}$ & $1.73^{b}$ & $1.17^{\mathrm{C}}$ & 0.05 & $<.001$ \\
\hline Thr & $3.97^{\mathrm{a}}$ & $3.59^{\mathrm{a}}$ & $2.46^{\mathrm{b}}$ & 0.15 & $<.001$ \\
\hline Trp & $2.07^{\mathrm{a}}$ & $1.44^{\mathrm{b}}$ & $1.33^{b}$ & 0.02 & $<.001$ \\
\hline Arg & $4.99^{\mathrm{a}}$ & $4.81^{\mathrm{a}}$ & $3.32^{b}$ & 0.08 & $<.001$ \\
\hline $\mathrm{His}$ & $3.19^{\mathrm{a}}$ & $3.06^{\mathrm{a}}$ & $1.75^{\mathrm{b}}$ & 0.06 & $<.001$ \\
\hline Ile & $3.69^{\mathrm{a}}$ & $3.11^{\mathrm{b}}$ & $2.08^{c}$ & 0.06 & $<.001$ \\
\hline Leu & $3.27^{\mathrm{a}}$ & $2.83^{b}$ & $1.99^{c}$ & 0.09 & 0.002 \\
\hline Phe & $3.23^{\mathrm{a}}$ & $3.04^{\mathrm{a}}$ & $1.80^{\mathrm{b}}$ & 0.08 & $<.001$ \\
\hline Val & $2.23^{\mathrm{a}}$ & $2.04^{a}$ & $1.47^{b}$ & 0.08 & $<.001$ \\
\hline Pro & $3.50^{\mathrm{a}}$ & $2.53^{b}$ & $2.68^{b}$ & 0.05 & $<.001$ \\
\hline Asn & $2.87^{\mathrm{a}}$ & $1.71^{\mathrm{b}}$ & $2.56^{\mathrm{ab}}$ & 0.12 & 0.015 \\
\hline Ser & $1.05^{\mathrm{a}}$ & $-1.69^{c}$ & $0.77^{\mathrm{b}}$ & 0.11 & $<.001$ \\
\hline Gln & $-14.9^{a}$ & $-20.8^{b}$ & $-16.1^{a}$ & 0.66 & $<.001$ \\
\hline Gly & $14.6^{\mathrm{a}}$ & $13.2^{\mathrm{b}}$ & $8.77^{c}$ & 0.18 & $<.001$ \\
\hline Ala & $16.5^{\mathrm{a}}$ & $14.1^{\mathrm{b}}$ & $10.6^{c}$ & 0.14 & $<.001$ \\
\hline Cys & $1.22^{\mathrm{a}}$ & $-0.63^{c}$ & $0.18^{b}$ & 0.09 & $<.001$ \\
\hline Tyr & $2.23^{a}$ & $0.97^{c}$ & $1.05^{b}$ & 0.09 & $<.001$ \\
\hline EAAs & $33.5^{\mathrm{a}}$ & $30.1^{b}$ & $20.3^{c}$ & 0.74 & $<.001$ \\
\hline NEAAs & $27.1^{\mathrm{a}}$ & $9.41^{c}$ & $10.5^{\mathrm{b}}$ & 1.01 & $<.001$ \\
\hline TAAs & $60.6^{\mathrm{a}}$ & $39.5^{b}$ & $30.8^{c}$ & 1.71 & $<.001$ \\
\hline $\mathrm{NH}_{3}$ & $69.8^{\mathrm{a}}$ & $50.8^{b}$ & $40.4^{c}$ & 2.13 & $<.001$ \\
\hline Urea & $-2.06^{\mathrm{a}}$ & $-1.50^{\mathrm{b}}$ & $-1.13^{c}$ & 0.02 & $<.001$ \\
\hline
\end{tabular}

Data are presented as means $(n=5)$

Abbreviations: Control 18.0\% CP, CP Crude protein, DM Dry matter, EAAs Essential amino acids, NEAAs Non-essential amino acids, LP 13.5\% CP, LP-DCA $13.5 \%$ CP $+100 \mathrm{mg}$ DCA $/ \mathrm{kg}$ DM, SEM Standard error of mean, TAAs Total amino acids

"A positive value means the amount of nitrogen-containing compound leaving the liver is less than that entering the liver; a negative value means the amount of nitrogen-containing compound leaving the liver is greater than that entering the liver

$a, b, c$ Values within a row with different superscripts differ significantly $(P<0.05)$

and LP-DCA groups showed reductions in urinary nitrogen excretion by $23.5 \%$ and $44.7 \%$, respectively, and reductions in fecal nitrogen of $35.0 \%$ and $38.6 \%$, respectively. Although the reductions in the fecal nitrogen excretion of the two groups were comparable, the reduction in urinary nitrogen excretion in pigs fed a DCA-supplemented LP diet was considerably higher than that of pigs fed the unsupplemented LP diet. In addition, compared with pigs fed the control diet, we found that the pigs fed a LP diet without DCA supplementation showed reduced nitrogen retention. These observations are similar to the findings of our earlier study [17] and other studies [8, 51], which have reported that nitrogen retention was reduced when the amount of dietary $\mathrm{CP}$ was reduced by $\geq 3 \%$. However, 
DCA supplementation compensated for the adverse effects of the LP diets on nitrogen retention in pigs, which is in accordance with our hypothesis that DCA may be a suitable dietary additive for reducing nitrogen excretion in pigs via an enhancement of nitrogen utilization efficiency. In this regard, we suspect that the mechanisms underlying the enhanced nitrogen utilization are related to the changes in nutrient metabolism in response to dietary DCA supplementation.

\section{Nutrient metabolism}

In a previous study, we demonstrated that the provision of a LP diet supplemented with Lys, Met, Thr, and Trp reduced the supply of NEAAs to the portal vein and increased the rate of EAA metabolism in the liver of pigs [17]. NEAAs play important roles in the synthesis of numerous bioactive compounds and the normal growth and maintenance of animals [52, 53]. The daily body weight gain and feed efficiency of growing pigs are reduced when the dietary NEAA supply is insufficient [9]. Therefore, we assume that an insufficient supply of NEAAs is a major disadvantage of LP diets. In the present study, although the net amount of NEAAs and TAAs released into the portal vein of pigs fed a DCAsupplemented LP diet were still lower than those of pigs fed the control diet, addition of DCA was observed to reduce the metabolism of EAAs and TAAs in the liver. Eventually the differences in the fluxes of NEAAs, EAAs, and TAAs across the hepatic vein between the control group and the pigs that received a LP diet were abolished. In addition, compared with pigs in the control and LP groups, pigs in the LP-DCA group showed a reduced release of $\mathrm{NH}_{3}$ into the portal vein and reduced urea production in the liver. These results indicate that supplementing a LP diet with DCA can enhance nitrogen utilization efficiency in pigs by increasing and optimizing the supply of amino acids to the liver and extrahepatic tissues, thereby reducing urea production in the liver and urinary nitrogen excretion. Notably, dietary DCA supplementation promoted a reduction in the catabolism of amino acids such as Glx $(\mathrm{Glu}+\mathrm{Gln})$ in the PDV, which are known to be major energy substrates in enterocytes and colonocytes and are beneficial for intestinal health $[16,54,55]$. Therefore, theoretically, dietary DCA supplementation may have some adverse effects on pigs, primarily on the intestines. We suggest that in future studies, more attention should be devoted to assessing the effects of DCA on intestinal health.

Recent evidence has indicated that gut microbiota in the intestines play an important role in dietary protein/ amino acid metabolism. Fermentation of amino acids by gut bacteria produces metabolites that can affect host protein/amino acid uptake (transport) and metabolism, as well as influenc host cell physiology [56]. Moreover, bacteria can synthesize certain amino acids for host utilization [57]. Reducing the amount of dietary protein has been viewed as an alternative option that can be used to reduce excessive protein fermentation in the large intestine of pigs [58]. This reduction can inhibit the growth of potential pathogens, such as species of Bacteroides and Clostridium, and reduce amino acid deamination [59]. These studies indicate that the reductions in nitrogen excreted in the feces and urine of pigs fed LP diets with or without DCA supplementation may be related to a reduction in the amino acid deamination activities of intestinal microbiota. However, given that we did not investigate the effects of DCA on the intestinal microbiota in this study, we were unable to test this hypothesis.

We assume that enhanced amino acid utilization efficiency is closely related to changes in energy utilization efficiency. The LP diets formulated in the present study were designed to be isocaloric with the control diet, which we achieved by increasing the proportion of carbohydrates in the diet. Accordingly, the LP diets were characterized as being LP high-starch diets. The net energy provided by starch is considerably higher than that provided by the protein [60]. Feeding LP diets has been found to reduce the amount of energy required for deamination of excess amino acids, lower body protein turnover and heat production, and enhance energy utilization efficiency [61]. In the present study, we observed that there were no significant differences in the digestive energy digestibility and metabolic energy/digestive energy ratio of pigs provisioned with the control and LP diets, although the values recorded for pigs in the LP group tended to be higher, whereas those for pigs in the LP-DCA group were significantly higher. Accordingly, these results indicate that the energy utilization efficiency of pigs was enhanced by dietary DCA supplementation.

Of note in this regard is the fact that DCA is similar to acetate, which is known to serve as a source of energy in several cell types, including intestinal cells, and has profound effects on gut metabolism and health [62]. Although, to the best of our knowledge, there is no direct evidence to indicate that DCA can be used as an energy substrate or energy precursor similar to acetate, the dose of DCA used in the present study was very low. Thus, we could effectively ignore the putative role of DCA as an energy substrate/energy precursor, even though DCA is functionally similar to acetate.

\section{Possible effect mechanisms of DCA}

We have previously shown that DCA supplementation can reduce the phosphorylation of PDK1 in porcine intestinal epithelial (IPEC-J2) cells and also promotes the 
phosphorylation of PDP1 and PDHA1 [28], which is consistent with the findings of other studies [32]. The phosphorylation of PDK and deactivation of PDH reduce carbohydrate flux [63, 64], whereas dephosphorylation and activation by PDP promote carbohydrate oxidation [65]. In addition, we have found that DCA supplementation increases cellular GDH1 activity and reduces GDH2 activity [28], the latter being responsible for catalyzing the conversion of glutamate to $\alpha$-ketoglutarate (a substrate in the TCA cycle); the former plays the opposite role. Thus, supplementation of a LP diet would, in theory, promote glucose oxidation, while reducing the amount of amino acids entering the TCA cycle.

\section{Conclusions}

In this study, we demonstrated that addition of DCA to LP diets can enhance the nitrogen utilization efficiency by increasing the amino acid supply from the intestines, reducing amino acid metabolism in the PDV and liver, and reducing the production of urea in the liver. Consequently, DCA supplementation increased the amino acid metabolic thrift and reduced nitrogen excretion without negatively affecting nitrogen retention in pigs fed a diet in which dietary $\mathrm{CP}$ was reduced by $4.5 \%$. However, even though we have demonstrated the value of DCA as a dietary supplement, a considerable amount of additional research is necessary to determine the effects of DCA on growth, immunity, and meat quality before DCA can be widely used in pig diets.

\section{Abbreviations}

AAs: Amino acids; CP: Crude protein; DCA: Sodium dichloroacetate; EAAs: Essential amino acids; GDH1: NADPH-dependent glutamate dehydrogenase; $\mathrm{GDH}_{2}$ : $\mathrm{NAD}^{+}$-dependent glutamate dehydrogenase; GLUT: Glucose transporter; HAPF: Hepatic artery plasma flow; HVPF: Hepatic vein plasma flow; IR: Infusion rate; NEAAs: Non-essential amino acids; $\mathrm{NH}_{3}$ : Ammonia; $\mathrm{PAH}$ : P-aminohippuric acid; $\mathrm{PAH}_{\mathrm{hv}}, \mathrm{PAH}_{\mathrm{ca}}$, and $\mathrm{PAH}_{\mathrm{pv}}$ : are the $\mathrm{PAH}$ concentrations in the hepatic vein, carotid artery, and portal vein, respectively; PDH: Pyruvate dehydrogenase; PDK: Pyruvate dehydrogenase kinase; PDP: Pyruvate dehydrogenase phosphatase; PVPF: Portal vein plasma flow; TAAs: Total amino acids

\section{Acknowledgements}

We thank Professor Yulong Yin, Professor Weiyun Zhu, and Professor Qingyan Jiang for their insightful suggestions on experimental design.

\section{Authors' contributions}

The authors' contributions are as follows: ZHS contributed to experimental design; WZS, YXL, ZRT, HYC, KW, RA, LTW, and ZHS conducted the animal and laboratory experiments, acquired and analyzed the data and interpreted the results; WZS, YXL, and ZHS contributed to manuscript writing and finalizing. All authors read and approved the final version of the manuscript and approved publication.

\section{Funding}

This study was funded by grants from the National Natural Science Foundation of China (31872370; 31670123), the Fundamental Research Funds for the Central Universities (XDJK2019B014; XDJK2013C097), and the Natural Science Foundation Project of CQ CSTC (cstc2018jcyjAX0025).

\section{Availability of data and materials}

The data analyzed during the current study are available from the corresponding author on reasonable request.

\section{Ethics approval}

All animal procedures such as ethical and animal welfare issues were approved by the ethics committee of Southwest University.

Consent for publication

Not applicable.

\section{Competing interests}

The authors declare that they have no competing interests.

\section{Author details}

${ }^{1}$ Laboratory for Bio-feed and Molecular Nutrition, College of Animal Science and Technology, Southwest University, Chongqing 400715, People's Republic of China. ${ }^{2}$ Institute of Animal Nutrition, Sichuan Agricultural University,

Chengdu 611130, People's Republic of China.

Received: 8 November 2019 Accepted: 17 February 2020

Published online: 13 April 2020

\section{References}

1. Uwizeye A, Gerber PJ, Opio Cl, Tempio G, Mottet A, Makkar HPS, et al. Nitrogen flows in global pork supply chains and potential improvement from feeding swill to pigs. Resour Conserv Recy. 2019;146:168-79. https:// doi.org/10.1016/j.resconrec.2019.03.032

2. Gallo L, Montà GD, Carraro L, Cecchinato A, Carnier P, Schiavon S. Growth performance of heavy pigs fed restrictively diets with decreasing crude protein and indispensable amino acids content. Livest Sci. 2014;161:130-8. https://doi.org/10.1016/j.livsci.2013.12.027.

3. Zhang S, Chu L, Qiao S, Mao X, Zeng X. Effects of dietary leucine supplementation in low crude protein diets on performance, nitrogen balance, whole-body protein turnover, carcass characteristics and meat quality of finishing pigs. Anim Sci J. 2016;87:911-20. https://doi.org/10.1111/ asj.12520.

4. Li Y, Li F, Duan Y, Guo Q, Wang W, Wen C, et al. The protein and energy metabolic response of skeletal muscle to the low-protein diets in growing pigs. J Agr Food Chem. 2017;65:8544-51. https://doi.org/10.1021/acs.jafc. $7 b 02461$.

5. Hinson RB, Schinckel AP, Radcliffe JS, Allee GL, Sutton AL, Richert BT. Effect of feeding reduced crude protein and phosphorus diets on weaningfinishing pig growth performance, carcass characteristics, and bone characteristics. J Anim Sci. 2009;87:1502-17. https://doi.org/10.2527/jas.20081325

6. Galassi G, Colombini S, Malagutti L, Crovetto GM, Rapetti L. Effects of high fibre and low protein diets on performance, digestibility, nitrogen excretion and ammonia emission in the heavy pig. Anim Feed Sci Tech. 2010;16: 1140-8. https://doi.org/10.1016/j.anifeedsci.2010.08.009.

7. Hong JS, Lee Gl, Jin XH, Kim YY. Effect of dietary energy levels and phase feeding by protein levels on growth performance, blood profiles and carcass characteristics in growing-finishing pigs. J Anim Sci Tech. 2016;58:37. https://doi.org/10.1186/s40781-016-0119-z.

8. Otto ER, Yokoyama M, Ku PK, Ames NK, Trottier NL. Nitrogen balance and ileal amino acid digestibility in growing pigs fed diets reduced in protein concentration. J Anim Sci. 2003;81:1743-53. https://doi.org/10.2527/2003. 8171743x.

9. He L, Wu L, Xu Z, Li T, Yao K, Cui Z, et al. Low-protein diets affect ileal amino acid digestibility and gene expression of digestive enzymes in growing and finishing pigs. Amino Acids. 2016;48:21-30. https://doi.org/10. 1007/s00726-015-2059-1.

10. Guay F, Donovan SM, Trottier NL. Biochemical and morphological developments are partially impaired in intestinal mucosa from growing pigs fed reduced-protein diets supplemented with crystalline amino acids. J Anim Sci. 2006;84:1749-60. https://doi.org/10.2527/jas.2005-558.

11. Mansilla WD, Htoo JK, de Lange CFM. Nitrogen from ammonia is as efficient as that from free amino acids or protein for improving growth performance of pigs fed diets deficient in nonessential amino acid nitrogen. J Anim Sci. 2017:95:3093-102. https://doi.org/10.2527/jas.2016.0959. 
12. Roux ML, Donsbough AL, Waguespack AM, Powell S, Bidner TD, Payne RL, et al. Maximizing the use of supplemental amino acids in corn-soybean meal diets for 20- to 45-kilogram pigs. J Anim Sci. 2011;89:2415-24. https:// doi.org/10.2527/jas.2010-3756.

13. Yue L, Qiao S. Effects of low-protein diets supplemented with crystalline amino acids on performance and intestinal development in piglets over the first 2 weeks after weaning. Livest Sci. 2008;115:144-52. https://doi.org/10. 1016/j.livsci.2007.06.018.

14. Patráš P, Nitrayová S, Brestenský M, Heger J. Effect of dietary fiber and crude protein content in feed on nitrogen retention in pigs. J Anim Sci. 2012;90: 158-60. https://doi.org/10.2527/jas.53837.

15. Shirali M, Doeschl-Wilson A, Knap PW, Duthie C, Kanis E, van Arendonk JA, et al. Nitrogen excretion at different stages of growth and its association with production traits in growing pigs. J Anim Sci. 2012;90:1756-65. https:// doi.org/10.2527/jas.2011-4547.

16. Burrin DG, Stoll B. Metabolic fate and function of dietary glutamate in the gut. Am J Clin Nutr. 2009;90:850S-6S. https://doi.org/10.3945/ajcn.2009. $27462 Y$.

17. Wu LT, Zhang XX, Tang ZR, Li YX, Li TJ, Xu QQ, et al. Low-protein diets decrease porcine nitrogen excretion but with restrictive effects on amino acid utilization. J Agr Food Chem. 2018;66:8262-71. https://doi.org/10.1021/ acs.jafc.8b03299.

18. Windmueller HG, Spaeth AE. Metabolism of absorbed aspartate, asparagine, and arginine by rat small intestine in vivo. Arch Biochem Biophys. 1976;175: 670-6. https://doi.org/10.1016/0003-9861(76)90558-0.

19. Reeds PJ, Burrin DG, Jahoor F, Wykes L, Henry J, Frazer EM. Enteral glutamate is almost completely metabolized in first pass by the gastrointestinal tract of infant pigs. Am J Phys. 1996;270:E413-8. https://doi. org/10.1016/0167-0115(95)00163-8.

20. Matthews DE, Marano MA, Campbell RG. Splanchnic bed utilization of glutamine and glutamic acid in humans. Am J Phys. 1993;264:848-54. https://doi.org/10.1152/ajpendo.1993.264.6.E848.

21. Stoll B, Henry J, Reeds PJ, Yu H, Jahoor F, Burrin DG. Catabolism dominates the first-pass intestinal metabolism of dietary essential amino acids in milk protein-fed piglets. J Nutr. 1998;128:606-14. https://doi.org/10.1093/jn/128.3. 606.

22. Kight CE, Fleming SE. Oxidation of glucose carbon entering the TCA cycle is reduced by glutamine in small intestine epithelial cells. Am J Phys. 1995;268: G879-88. https://doi.org/10.1152/ajpgi.1995.268.6.G879.

23. Le A, Lane AN, Hamaker M, Bose S, Gouw A, Barbi J, et al. Glucoseindependent glutamine metabolism via TCA cycling for proliferation and survival in B-cells. Cell Meta. 2012;15:110-21. https://doi.org/10.1016/j.cmet. 2011.12.009.

24. Reeds PJ, Burrin DG, Stoll B, Jahoor F, Frazer ME. Enteral glutamate is the preferential source for mucosal glutathione synthesis in fed piglets. Am J Phys. 1997;273:E408-15. https://doi.org/10.1152/ajpendo.1997.273.2.E408.

25. Alican I, Kubes P. A critical role for nitric oxide in intestinal barrier function and dysfunction. Am J Physiol-Gastr L. 1996;270:G225-37. https://doi.org/10. 1152/ajpgi.1996.270.2.G225.

26. Burrin DG, Reeds PJ. Alternative fuels in the gastrointestinal tract. Curr Opin Gastroenterol. 1997;13:165-70. https://doi.org/10.1097/00001574-19970300000015.

27. Li YX, Tang ZR, Li TJ, Chen C, Huang FR, Yang J, et al. Pyruvate is an effective substitute for glutamate in regulating porcine nitrogen excretion. J Anim Sci. 2018;96:3804-14. https://doi.org/10.1093/jas/sky237.

28. An R, Tang ZR, Li YX, Li TJ, Xu QQ, Zhen JF, et al. Activation of pyruvate dehydrogenase by sodium dichloroacetate shifts metabolic consumption from amino acids to glucose in IPEC-J2 cells and intestinal bacteria in pigs. Agr Food Chem. 2018;66:3793-800. https://doi.org/10.1021/acs.jafc.7b05800.

29. Bricker DK, Taylor EB, Schell JC, Orsak T, Boutron A, Chen YC, et al. A mitochondrial pyruvate carrier required for pyruvate uptake in yeast, Drosophila, and humans. Science. 2012;337:96-100. https://doi.org/10.1126/ science.1218099

30. Gray LR, Sultana MR, Rauckhorst AJ, Oonthonpan L, Tompkins SC, Sharma A, et al. Hepatic mitochondrial pyruvate carrier 1 is required for efficient regulation of gluconeogenesis and whole-body glucose homeostasis. Cell Meta. 2015;22:669-81. https://doi.org/10.1016/j.cmet.2015.07.027.

31. Michelakis ED, Webster L, Mackey JR. Dichloroacetate (DCA) as a potential metabolic-targeting therapy for cancer. Br J Cancer. 2008;99:989-94. https:// doi.org/10.1038/sj.bjc.6604554.
32. Kato M, Li J, Chuang JL, Chuang DT. Distinct structural mechanisms for inhibition of pyruvate dehydrogenase kinase isoforms by AZD7545, dichloroacetate, and radicicol. Structure. 2007;15:992-1004. https://doi.org/ 10.1016/j.str.2007.07.001.

33. Madhok BM, Yeluri S, Perry SL, Hughes TA, Jayne DG. Dichloroacetate induces apoptosis and cell-cycle arrest in colorectal cancer cells. Br J Cancer. 2010;102:1746-52. https://doi.org/10.1038/bjc.2014.281.

34. Babu E, Ramachandran S, Coothankandaswamy V, Elangovan S, Prasad PD, Ganapathy $V$, et al. Role of SLC5A8, a plasma membrane transporter and a tumor suppressor, in the antitumor activity of dichloroacetate. Oncogene. 2010;30:4026-37. https://doi.org/10.1038/onc.2011.113.

35. Sanchez-Arago M, Chamorro M, Cuezva JM. Selection of cancer cells with repressed mitochondria triggers colon cancer progression. Carcinogenesis. 2011;31:567-76. https://doi.org/10.1093/carcin/bgq012.

36. Naito E, Kuroda Y, Toshima K, Takeda E, Saijo T, Kobashi H, et al. Effect of sodium dichloroacetate on human pyruvate metabolism. Brain and Development. 1989;11:195-7. https://doi.org/10.1016/S0387-7604(89)800981.

37. Berendzen K, Theriaque DW, Shuster J, Stacpoole PW. Therapeutic potential of dichloroacetate for pyruvate dehydrogenase complex deficiency. Mitochondrion. 2006:6:126-35. https://doi.org/10.1016/j.mito.2006.04.001.

38. Stacpoole PW, Barnes CL, Hurbanis MD, Cannon SL, Kerr DS. Treatment of congenital lactic acidosis with dichloroacetate. Arch Dis Child. 1997;77:53541. https://doi.org/10.1136/adc.77.6.535.

39. Stacpoole PW, Kerr DS, Barnes C, Bunch ST, Carney PR, Fennell EM, et al. Controlled clinical trial of dichloroacetate for treatment of congenital lactic acidosis in children. Pediatrics. 2006;117:1519-31. https://doi.org/10.1542/ peds.2005-1226.

40. Liu D, Wang F, Yue J, Jing X, Huang Y. Metabolism targeting therapy of dichloroacetate-loaded electrospun mats on colorectal cancer. Drug Deliv. 2015;22:136-43. https://doi.org/10.3109/10717544.2013.870258.

41. NRC. Nutrient Requirements of Swine. 11th ed. Washington, DC: National Academy Press; 2012.

42. Stacpoole PW, Neiberger RE, Carney PR, Valenstein E, Theriaque DW, Shuster JJ. Evaluation of long-term treatment of children with congenital lactic acidosis with dichloroacetate. Pediatrics. 2008;121:e1223-8. https://doi.org/ 10.1542/peds.2007-2062.

43. AOAC. Official methods of analysis. 17th revision. Association of Official Analytical Chemists: Arlington, MA; 2000.

44. Myers WD, Ludden PA, Nayigihugu V, Hess BW. Technical note: a procedure for the preparation and quantitative analysis of samples for titanium dioxide. J Anim Sci. 2004;82:179-83. https://doi.org/10.2527/2004.821179x.

45. Pan L, Ma XK, Wang HL, Xu X, Zeng ZK, Tian QY, et al. Enzymatic feather meal as an alternative animal proteinsource in diets for nursery pigs. Anim Feed Sci Tech. 2015;212:112-21. https://doi.org/10.1016/j.anifeedsci.2015.12. 014.

46. Yen JT, Killefer J. A method for chronically quantifying net absorption of nutrients and gut metabolites into hepatic portal vein in conscious swine. J Anim Sci. 1987;64:923-34. https://doi.org/10.2527/jas1987.643923x.

47. Harvey RB, Brothers AJ. Renal extraction of Para-aminohippurate and creatinine measured by continuous in vivo sampling of arterial and renalvein blood. Ann N Y Acad Sci. 1962;102:46-53. https://doi.org/10.1111/j. 1749-6632.1962.tb13624.x.

48. Fernández-Fígares I, Lachica M, Rojas-Cano ML, González-Casado A. Influence of Para-aminohippuric acid analysis on net portal-drained viscera flux of nutrients in pigs. Animal. 2018;12:232-8. https://doi.org/10.1017/ s1751731117001598.

49. Li L, Zhang P, Zheng P, Bao Z, Wang Y, Huang FR. Hepatic cumulative net appearance of amino acids and related gene expression response to different protein diets in pigs. Livest Sci. 2015;182:11-21. https://doi.org/10. 1016/j.livsci.2015.10.012.

50. Zhu LH, Armentano LE, Bremmer DR, Grummer RR, Bertics SJ. Plasma concentration of urea, ammonia, glutamine around calving, and the relation of hepatic triglyceride, to plasma ammonia removal and blood acid-base balance. J Dairy Sci. 2000;83:734-40. https://doi.org/10.3168/jds.S00220302(00)74935-6.

51. Figueroa JL, Lewis AJ, Miller PS, Fischer RL, Gómez RS, Diedrichsen RM. Nitrogen metabolism and growth performance of gilts fed standard cornsoybean meal diets or low-crude protein, amino acid-supplemented diets. J Anim Sci. 2002:80:2911-9. https://doi.org/10.2527/2002.80112911x. 
52. Rhoads $J M$, Wu G. Glutamine, arginine, and leucine signaling in the intestine. Amino Acids. 2009;37:111-22. https://doi.org/10.1007/s00726-0080225-4.

53. Wu G, Bazer FW, Dai Z, Li D, Wang J, Wu Z. Amino acid nutrition in animals: protein synthesis and beyond. Annu Rev Anim Biosci. 2014;2:387-417. https://doi.org/10.1146/annurev-animal-022513-114113.

54. Newsholme P, Procopio J, Lima MM, Pithon-Curi TC, Curi R. Glutamine and glutamate-their central role in cell metabolism and function. Cell Biochem Funct. 2003;21:1-9. https://doi.org/10.1002/cbf.1003.

55. Riedijk MA, de Gast-Bakker DA, Wattimena JL, van Goudoever JB. Splanchnic oxidation is the major metabolic fate of dietary glutamate in enterally fed preterm infants. Pediatr Res. 2007;62:468-73. https://doi.org/10.1203/PDR. Ob013e31813cbeba.

56. Davila AM, Blachier F, Gotteland M, Andriamihaja M, Benetti PH, Sanz Y, et al. Intestinal luminal nitrogen metabolism: Role of the gut microbiota and consequences for the host. Pharmacol Res. 2013;69:114-26. https://doi. org/10.1016/.phrs.2012.11.005.

57. Metges CC. Contribution of microbial amino acids to amino acid homeostasis of the host. J Nutr. 2000;130:1857S-64S. https://doi.org/10. 1093/jn/130.7.1857S.

58. Heo JM, Kim JC, Hansen CF, Mullan BP, Hampson DJ, Pluske JR. 2008. Effects of feeding low protein diets to piglets on plasma urea nitrogen, faecal ammonia nitrogen, the incidence of diarrhoea and performance after weaning. Arch Anim Nutri. 2008;62:343-58. https://doi.org/10.1080/ 17450390802327811.

59. Macfarlane S, Macfarlane GT. Proteolysis and amino acid fermentation. In: Gibson GR, Macfarlane GT, editors. Human colonic bacteria: role in nutrition, physiology and pathology. Boca Raton (Florida): CRC Press; 1995. p. 75-100.

60. Noblet J, Fortune H, Shi XS, Dubois S. Prediction of net energy value of feeds for growing pigs. J Anim Sci. 1994;72:344-54. https://doi.org/10.1016/ 0168-1591(94)90137-6.

61. Noblet J, Henry Y, Dubois S. Effect of protein and lysine levels in the diet on body gain composition and energy utilization in growing pigs. J Anim Sci. 1987;65:717-26. https://doi.org/10.1051/gse:19870309.

62. Tremaroli V, Bäckhed F. Functional interactions between the gut microbiota and host metabolism. Nature. 2012;489:242-9. https://doi.org/10.1038/ nature11552.

63. Denton RM, Randle PJ, Bridges BJ, Cooper RH, Kerbey AL, Pask HT, et al. Regulation of mammalian pyruvate dehydrogenase. Mol Cell Biochem. 1975;9:27-53. https://doi.org/10.1007/BF01731731.

64. Wieland $\mathrm{OH}$. The mammalian pyruvate dehydrogenase complex: structure and regulation. Rev Physiol Biochem Pharmacol. 1983;96:123-70. https://doi. org/10.1007/BFb0031008.

65. Leblanc PJ, Mulligan M, Antolic A, Macpherson L, Inglis JG, Martin D, et al. Skeletal muscle type comparison of pyruvate dehydrogenase phosphatase activity and isoform expression: effects of obesity and endurance training. Am J Physiol Regul Integr Comp Physiol. 2008;295:R1224-30. https://doi.org/ 10.1152/ajpregu.90320.2008.

Ready to submit your research? Choose BMC and benefit from:

- fast, convenient online submission

- thorough peer review by experienced researchers in your field

- rapid publication on acceptance

- support for research data, including large and complex data types

- gold Open Access which fosters wider collaboration and increased citations

- maximum visibility for your research: over $100 \mathrm{M}$ website views per year

At $\mathrm{BMC}$, research is always in progress.

Learn more biomedcentral.com/submissions 